ENTREPRENEURSHIP AND SUSTAINABILITY ISSUES

ISSN 2345-0282 (online) http://jssidoi.org/jesi/

2020 Volume 8 Number 2 (December)

http://doi.org/10.9770/jesi.2020.8.2(42)
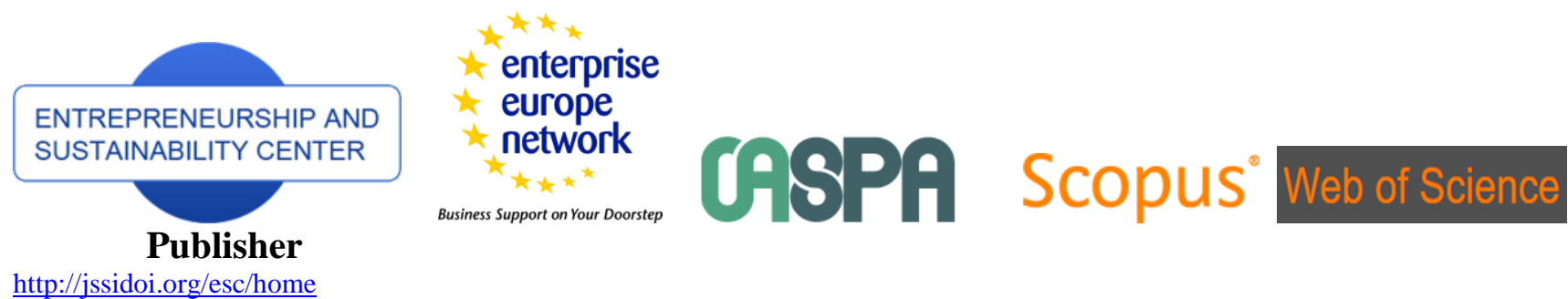

http://jssidoi.org/esc/home

Business Support on Your Doorstep

1 Clarivate

Analytics

\title{
SUSTAINABLE DEVELOPMENT OF SMART CITIES IN THE CONTEXT OF THE IMPLEMENTATION OF THE TIRE RECYCLING PROGRAM*
}

\author{
Tatyana Khudyakova ${ }^{1}$, Andrey Shmidt ${ }^{2}$, Svetlana Shmidt ${ }^{3}$ \\ ${ }_{1,2}$ South Ural State University, Department of Applied Economics, 76, Lenin av., Chelyabinsk, Russia \\ ${ }^{3}$ Saint-Petersburg State University, Department of Mathematics and Computer Science, Saint-Petersburg, Russia \\ E-mails: ${ }^{1}$ khudiakovata@susu.ru; ${ }^{2}$ shmidtav@susu.ru; ${ }^{3}$ lana0771711@gmail.com
}

Received 8 May 2020; accepted 11 September 2020; published 30 December 2020

\begin{abstract}
At the present moment of society's development, the concept of Smart City development is attracting more and more attention. According to this approach, urban space should be implemented from the position of improving the quality of life of citizens. As part of the development of a smart city, rational and economical use of resources is assumed. This attitude to resources allows not only to save resources but also to improve the quality of life of the population, particularly by improving the environmental situation in the regions. In the world practice of developing cities, the recycling processes are becoming more and more relevant. On the one hand, this saves material and energy resources. On the other hand, these measures help to improve the quality of the environment in the regions. Recently, two concepts have become a trend in the development of urban economy in world practice. One of them is the concept of a smart city, the other is the concept of sustainable urban development. Despite a number of differences, both approaches to city management imply a focus on environmental friendliness. Implementing strategies of development of Russian cities in the framework of the concept of sustainable development and within the concept of smart cities aims to improve the environmental situation in the country. Therefore, the aim of the research was to improve the environmental potential of Russian regions through the use of modern Russian and foreign research, in particular through the tire recycling program. For Russia, one of the key environmental problems is the problem of recycling car tires. Despite the emergence of new eco-friendly ways of recycling tire waste, it is becoming more acute every year. This is understandable, because the number of cars increases every year. Currently, decommissioned tires are a source of environmental pollution in most of the Russian regions. However, this source of pollution is a long-term source. This is due to the fact that worn tires are practically not susceptible to natural decomposition, and, as a result, require increasing space for their storage and disposal. The article provides an analysis of the dynamics and prospects of car tire recycling in the framework of the concept of sustainable development of smart cities. A comparative analysis of the state of this issue in Russian and foreign practice is presented. In addition, according to statistic analysis, the article provides a forecast analysis of the increase in waste in the form of tires and an analysis of the regulatory framework governing the recycling process.
\end{abstract}

Keywords: smart city; sustainable city; circular economy; waste management; economic effect; resource-saving technologies; tire recycling

\footnotetext{
* The work was supported by Act 211 Government of the Russian Federation, contract № 02.A03.21.0011.
} 
ENTREPRENEURSHIP AND SUSTAINABILITY ISSUES

ISSN 2345-0282 (online) http://jssidoi.org/jesi/

2020 Volume 8 Number 2 (December)

http://doi.org/10.9770/jesi.2020.8.2(42)

Make your research more visible, join the Twitter account of ENTREPRENEURSHIP AND SUSTAINABILITY ISSUES: @Entrepr69728810

Reference to this paper should be made as follows: Khudyakova, T., Shmidt, A., Shmidt, S. 2020. Sustainable development of smart cities in the context of the implementation of the tire recycling program. Entrepreneurship and Sustainability Issues, 8(2), 698-715. http://doi.org/10.9770/jesi.2020.8.2(42)

JEL Classifications: G32, M40, Q01, O10, O21

\section{Introduction}

According to the McKinsey Agency, there are about 200 smart cities in the world today. The most developed in this area include London, Singapore, Seoul, New York, Helsinki, Montreal, Boston, Melbourne, Barcelona, and Shanghai. At the same time, there are practically no Russian regions in the international smart city rankings, with the exception of Moscow, St. Petersburg, and Novosibirsk, which are also far from leading positions. At the same time, by the end of 2025, it is planned that there will be about 600 smart cities in the world (Urban world: Mapping the economic power of cities, 2011). This means that the number of smart cities in the world should increase by 3 times. This makes it necessary to develop approaches to creating and managing Smart City development as soon as possible (Machado, 2017).

The Ministry of construction of the Russian Federation has adopted a pilot project to create a Smart City on the basis of Russian cities. In addition, 8 Russian cities such as Krasnodar, Innopolis, Tolyatti, Novorossiysk, Sarov, Sochi, Voronezh and Magas are part of the International Smart Sustainable City Club (ISSCC).

However, today there is no clear approach to the concept of "Smart City". But having studied the world's leading practices, we agree that a smart city is a new approach to the implementation of urban space based on the use of digital technologies, based on the principles of:

$\checkmark \quad$ the open space;

$\checkmark \quad$ management transparency;

$\checkmark \quad$ involvement of citizens in the management process;

$\checkmark \quad$ improving the quality of life (Saptadi et al., 2019).

Smart city combines several elements such as:

$\checkmark \quad$ smart environment (renewable energy, resource saving, etc);

$\checkmark \quad$ smart mobility (transport networks, smart parking, wifi coverage, etc.);

$\checkmark \quad$ smart lifestyle (comfortable structure of the city, health saving technologies, etc.);

$\checkmark \quad$ smart people (educated, able to participate in urban processes using ICT).

$\checkmark \quad$ smart economy (Saptadi et al., 2019).

Thus, a "smart city" is a city that strives to ensure sustainable development in all plans (economic, social, political), as well as a high quality and standard of living with reasonable management of natural resources and the environment, while using digital and information technologies, data collection, processing and analysis technologies, as well as technical solutions and appropriate infrastructure (Novikov et al., 2019; Rostova et al., 2019).

Thus, one of the important elements of forming a smart city system is the rational use of resources, which allows to save resources, as well as improve the quality of life, including by improving the environmental situation in the regions (Sienkiewicz et al., 2017). 


\section{ENTREPRENEURSHIP AND SUSTAINABILITY ISSUES}

ISSN 2345-0282 (online) http://jssidoi.org/jesi/

2020 Volume 8 Number 2 (December)

http://doi.org/10.9770/jesi.2020.8.2(42)

Make your research more visible, join the Twitter account of ENTREPRENEURSHIP AND SUSTAINABILITY ISSUES: @Entrepr69728810

In the world practice of developing smart cities, recycling processes are becoming more and more popular. On the one hand, this saves material and energy resources. On the other hand, this makes it possible to improve the quality of the environment in the regions (Ahvenniemi et al., 2017).

One of the key environmental problems in Russia is the problem of recycling car tires. It is becoming more acute despite the emergence of new eco-friendly ways to dispose of them. This is due to an increase in the number of cars.

However, similar problems are not unique to Russian cities. In this regard, it becomes very relevant to analyze the current state, as well as to identify the prospects for the development of municipalities from the perspective of sustainable development of smart cities.

Thus, the goal of the research is to increase the environmental potential of Russian cities within the framework of the implementation of the concept of sustainable development and the concept of smart cities, in particular through adequate utilization of tire waste.

The following problems should be resolved to achieve the goal:

1. Analysis of international urban development practices in accordance with the concept of sustainable development and the concept of a smart city from the point of improving the environmental component, in particular through adequate utilization of tire waste.

2. Identification of trends in tire waste disposal in international and Russian practice with a focus on sustainable development of territories.

3. Detection of the potential for the development of Russian cities in the framework of the concept of sustainable development and the concept of smart cities based on the analysis

\section{Theoretical Framework and Literature Review}

Countries are increasingly faced with the need to improve the efficiency and competitiveness of their economies. This is due to hyper-competition in the global market. However, for further development of production, it is necessary to increase the consumption of resources. This causes a huge increase in production waste. This becomes critical for the future existence of the society.

A similar problem was raised by Ahvenniemi et al. (2017). They note that, as expected, modern cities place much more emphasis on modern technology and "smartness" compared to urban sustainability concepts. At the same time, they emphasize that the environmental component is also important in the development of the smart city concept. In addition, they note that it is extremely important that when assessing the effectiveness of a smart city, not only indicators of the effectiveness of smart solutions are used, but also impact indicators that measure the contribution to the achievement of final goals, such as environmental, economic or social sustainability.

The need for a symbiosis of the concepts of "smart" and "sustainable" urban development is considered by Nižetić et al. (2019). In their opinion, it is intellectual technologies that will allow society to have a sustainable future. The main goal of modern society is sustainability and reasonable use of limited and valuable resources. However, as the authors note, there are completely different approaches and standards to sustainable development in society, which depend on geographical, temporal and cultural aspects. 


\section{ENTREPRENEURSHIP AND SUSTAINABILITY ISSUES}

ISSN 2345-0282 (online) http://jssidoi.org/jesi/

2020 Volume 8 Number 2 (December)

http://doi.org/10.9770/jesi.2020.8.2(42)

Make your research more visible, join the Twitter account of ENTREPRENEURSHIP AND SUSTAINABILITY ISSUES: @Entrepr69728810

Analysis of the current state of cities in the framework of two concepts "smart city" and "sustainable city" is considered in the study of Shmelev and Shmeleva (2018). This research analyzes more than 90 cities around the world. The results of the study showed that San Francisco leads in economic and environmental priorities, while Stockholm leads in social and smart urban priorities. Seoul is performing well across the entire spectrum of indicators.

Zhang et al. (2019), looking at the example of the Chinese economy, note that, of course, it is necessary to create a new type of management thinking aimed at the transition to a "circular economy with zero waste" (Zhang et al., 2019). They note that this is particularly relevant for China. At the same time, the study says that this problem is extremely complex, because it involves many stakeholders. The research highlights twelve important barriers to intelligent waste management in China. Among the strongest barriers, the authors highlight "the lack of regulatory pressure, the lack of environmental education and culture of environmental protection, as well as the lack of market pressure and requirements." Also, among the problems mentioned are smart waste management, the lack of a legal framework for mandatory waste disposal, and economic and financial problems related to the lack of funding.

Similar barriers to spreading the concepts of a "smart" and simultaneously "sustainable" city are noted in the work of Zhang et al. (Zhang et al., 2018).

Thus, it is clear that the creation of smart solutions for the organization of urban economy does not always provide for the environmental sustainability of these solutions.

For example, increasing transport accessibility as part of the development of the smart city concept, and the influx of people to these cities lead to an increase in the number of cars. This creates a problem associated with the disposal of failed cars and their parts.

The problem of increasing waste in the form of automobile tires has affected all developed countries. At present, this problem is receiving a lot of attention, both from the scientific community and from Governments.

At the same time, tire waste can be a good source of raw materials (Fagundes, 2017). This will not only solve environmental problems but also save financial resources.

So in their research Sienkiewicz et al. (2017) came to a number of conclusions based on a comprehensive review of changes in policies and approaches to tire recycling. First, the recycling and restoration of tires is a serious environmental problem due to their very complex structure and composition. Secondly, the governments of many countries are interested in developing new technologies for environmentally friendly recycling of tires. They note that there has been significant progress in sustainable waste management recently. This new approach is already being applied in the US, China, Japan and the EU. Also, the authors' note that used tires should not be considered as a pollutant, but as a source of materials.

Sienkiewicz et al. (2017) remark that already known technologies can be used for recycling tire waste. Thus, these measures do not require significant investment. But at the same time, they allow for "sustainable and clean recycling". It's good for both concepts - "smart city" and "sustainable urban development".

Gupta et al. also focused on waste recycling from the perspective of economic development (Gupta et al., 2019). 
ENTREPRENEURSHIP AND SUSTAINABILITY ISSUES

ISSN 2345-0282 (online) http://jssidoi.org/jesi/

2020 Volume 8 Number 2 (December)

http://doi.org/10.9770/jesi.2020.8.2(42)

Make your research more visible, join the Twitter account of ENTREPRENEURSHIP AND SUSTAINABILITY ISSUES: @Entrepr69728810

In their research Pereira et al. (Pereira et al., 2018), based on data from Brazil, tried to deduce the correlation between the number of tires coming for recycling and external factors. This research assumes forecasting the percentage of utilization under different conditions.

A large group of scientific papers is devoted to the re-use of waste. In particular, considering tire waste as raw materials. The work notes that on the one hand, proper recycling of tire waste will reduce the level of environmental pollution, and on the other hand, will allow you to get an additional economic effect.

Thus, in their article, Arulrajaha et al. (2019) note that used tires are indeed a big problem for sustainable urban development. At the same time, they suggest using this raw material as the basis for road pavement (sidewalks). They say that the increased strength of this type of coating. This approach also fits well into both the concepts of "smart city" and "sustainable urban development".

Similar conclusions were reached by Wang et al. (2019). The rapid growth in the number of cars in China has generated an increase in tire waste. At the same time, it is noted that currently $62.8 \%$ of tire waste is not processed in China. As a solution to the problem with recycling, the authors proposed adding rubber crumbs to the asphalt concrete pavement. They note that this will "contribute to the sustainable management of worn tires." And the use of crumb for asphalt production will be on the one hand "an effective method of balancing the contradictions between the supply and demand of rubber crumb", and on the other hand will significantly reduce carbon emissions into the atmosphere. In addition, the authors note that this data will reduce the dependence on nonrenewable resources in the production of asphalt.

Thus, urban management in the context of the implementation of two concepts at once: the concept of "Smart city" and the concept of "Sustainable urban development", of course, should become a driver of development.

However, there are factors that negatively affect the implementation of these concepts.

Ghosh et al. (2019) note that there are already many promising technologies for processing various types of waste. These technologies fully correspond to the concept of smart cities development. However, these methods are either not used at all, or are not fully used. This is particularly true in developing countries.

The same opinion is present in the work of M. Maryono and I. Hasmantika (2019). They believe that a number of technologies developed in advanced countries still cannot be applied in "cities of developing countries" because of their complexity. In addition, the authors note that the lack of environmental education of the population, as well as the lack of regulatory documents on waste disposal and recycling, greatly affects the development of cities within the framework of the concept of a smart and sustainable city.

Dong and Fujita (2015) note that it is difficult for society to balance economic growth with a low level of environmental pollution, in particular waste from burning tires. They note that in the framework of the development of society it is necessary to rely on the practice of Japanese cities with low carbon emissions. It focuses on two national initiatives: the eco-city project and the smart city project. The authors believe that applying this practice to Chinese cities will dramatically reduce carbon emissions into the atmosphere. 
ENTREPRENEURSHIP AND SUSTAINABILITY ISSUES

ISSN 2345-0282 (online) http://jssidoi.org/jesi/

2020 Volume 8 Number 2 (December)

http://doi.org/10.9770/jesi.2020.8.2(42)

Make your research more visible, join the Twitter account of ENTREPRENEURSHIP AND SUSTAINABILITY ISSUES: @Entrepr69728810

\section{Materials and Methods}

\subsection{The importance of tire recycling in the in the Russian Federation}

Currently, decommissioned tires are a source of environmental pollution in most of the Russian regions. However, this source of pollution is a long-term source. This is due to the fact that worn tires are almost not susceptible to natural decomposition. As a result, they require more and more space for their storage and disposal.

Today, there are certain strategies for dealing with worn tires. The most common ones are:

$\begin{array}{ll}\checkmark & \text { reuse; } \\ \checkmark & \text { export; } \\ \checkmark & \text { recovery; } \\ \checkmark & \text { mechanical processing; } \\ \checkmark & \text { thermal processing; } \\ \checkmark & \text { burial. }\end{array}$

However, the latter two approaches are not acceptable within the framework of the concept of sustainable regional development, as well as the concept of Smart City, which implies significant attention to environmental issues.

According to statistics, only about $20 \%$ of used tires are recycled in Russian regions (Rostova et al., 2019).

At the same time, worn tires are an excellent source of recyclable materials. They contain rubber, carbon black (almost pure carbon), metal and synthetic cord. In this case, the rubber is $70 \%$ of the weight of the worn tire. (Wang et al., 2020).

If incineration is used as a measure to dispose of tires, a large amount of toxic waste is released into the atmosphere. These emissions are several times higher than when burning coal (table 1), which also completely contradicts the concept of "smart cities" development:

Table 1. Emissions of pollutants into the atmosphere

\begin{tabular}{|l|c|l|}
\hline \multicolumn{1}{|c|}{ Pollutant } & Coal combustion & \multicolumn{1}{|c|}{ Burning of worn tires } \\
\hline Sulfur, \% & 2.00 & $1.3-2.2$ \\
\hline Ash, \% & 11.30 & $12.5-18.6$ \\
\hline Chlorine, \% & 0.14 & 0.20 \\
\hline Zinc, particles per million air particles & 27.20 & $9300-20500$ \\
\hline Chrome, particles per million air particles & 20.50 & 97.0 \\
\hline Nickel, particles per million air particles & 16.90 & 77.0 \\
\hline Plumbum, particles per million air particles & 8.30 & $60-760$ \\
\hline Cadmium, particles per million air particles & 0.91 & $5-10$ \\
\hline
\end{tabular}

Source: compiled by the authors based on (Rostova et al., 2019) 
Make your research more visible, join the Twitter account of ENTREPRENEURSHIP AND SUSTAINABILITY ISSUES: @Entrepr69728810

Thus, the problem of recycling worn-out car tires is a common problem that faces all industrialized countries. The solution to this problem is of great environmental and economic importance (table 2).

Table 2. Value of tire recycling in the context of the Smart City concept

\begin{tabular}{|l|ccc|}
\hline Value & \multicolumn{1}{|c|}{ Essence } \\
\hline Environmental & $\checkmark$ & $\begin{array}{l}\text { Tires that are located for a long time in organized landfills or on other territories are a source of } \\
\text { environmental pollution. }\end{array}$ \\
$\checkmark$ & They have a high degree of fire hazard. \\
$\checkmark$ & In the case of burning tires, the process is accompanied by emissions (about 150 different toxic \\
& $\checkmark$ & compounds), which are dangerous to human health and the environment. \\
\hline Economic & $\checkmark$ & $\begin{array}{l}\text { Worn tires are a valuable resource. At the same time, tire recycling becomes a priority task in conditions } \\
\text { of resource constraints. Recycled raw materials can be reused in various areas of production. }\end{array}$ \\
& $\checkmark$ & The elimination of tire dumps allows for the release of significant land areas for their more rational use. \\
\hline
\end{tabular}

In this regard, the issue of improving the quality of life, as well as issues of resource-saving technologies, which have become relevant in the context of the irreplaceability of material resources, become a priority in the development of the concept of smart cities.

\subsection{Analysis of foreign experience in tire waste disposal}

The number of cars on the planet is growing rapidly (figure 1), and the dynamics is exponential. Accordingly, the amount of waste generated increases in proportion to the increase in the number of vehicles. Over the past 20 years, the number of worn tires has increased by about 2 times (Novikov et al., 2019).

Figure 1 confirms that the challenge of recycling used tires is currently a much bigger problem for Russia than for developed foreign countries. Over the past 20 years, the number of passenger cars in Russia has increased by more than 3 times. Consequently, the number of tires in need of recycling has increased proportionally. 
Make your research more visible, join the Twitter account of ENTREPRENEURSHIP AND SUSTAINABILITY ISSUES: @Entrepr69728810

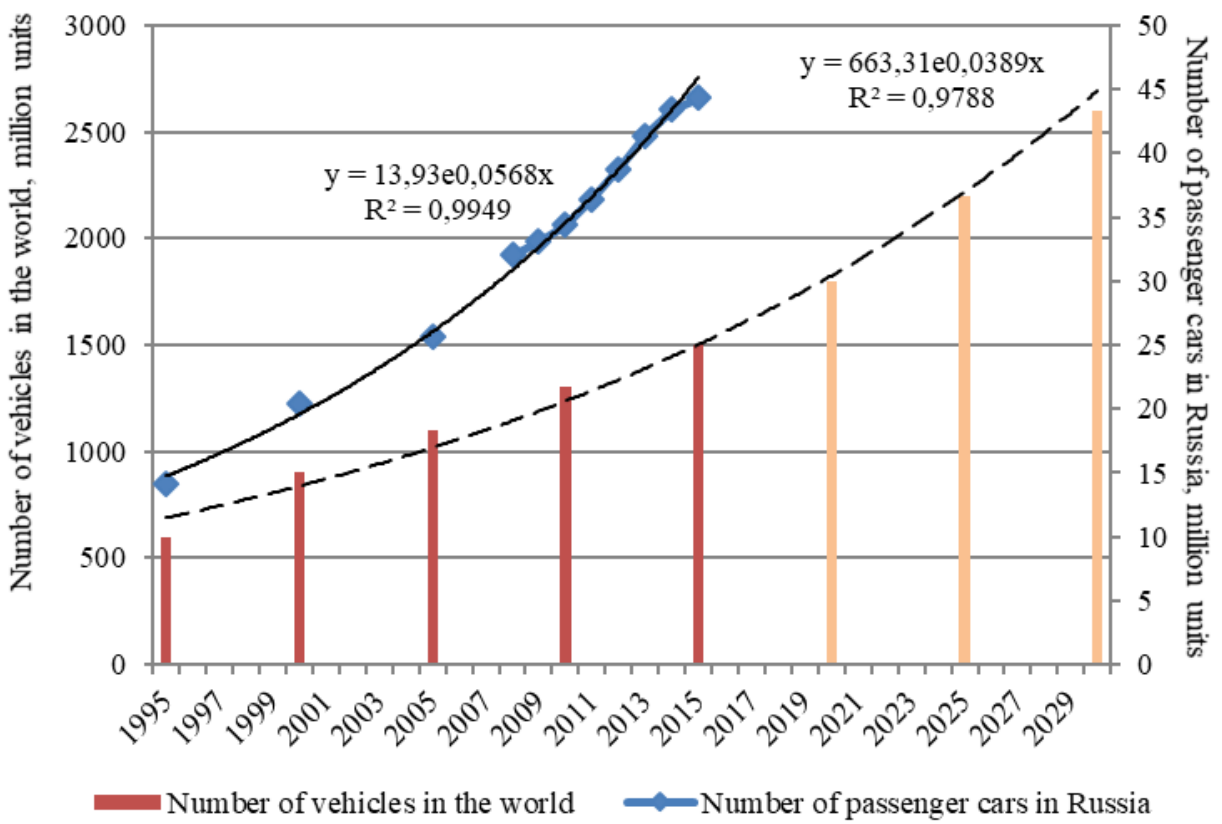

Fig 1. Dynamics of the number of vehicles

Source: compiled by the authors based on (Novikov et al., 2019)

At the same time, the global amount of tire waste according to various estimates ranges from 60 to 80 million tons. The annual increase is approximately 10 million tons of tires (Novikov et al., 2019). Thus, the annual growth rate exceeds $10 \%$. Only in the US, 4.3-4.5 million tons of worn tires are produced per year, in Europe-up to 3 million tons, in Japan - about 1 million tons (Novikov et al., 2019).

However, this is not the case in all countries. For example, in developed countries: Japan, Germany, and the Scandinavian countries, the recycling rate of tires is approaching $100 \%$. If we talk about Europe as a whole, we have determined the average utilization rate, which exceeded $76 \%$, based on table 3 (table 3 ).

Table 3. Analysis of tire recycling in Europe

\begin{tabular}{|c|c|c|c|c|c|c|}
\hline \multirow[t]{2}{*}{ Country } & \multirow{2}{*}{$\begin{array}{l}\text { Number of } \\
\text { tires, million } \\
\text { tons }\end{array}$} & \multicolumn{3}{|c|}{ Tire recycling, million tons } & \multirow{2}{*}{$\begin{array}{c}\text { Tire recycling, } \\
\%\end{array}$} & \multirow[t]{2}{*}{ Rank } \\
\hline & & Construction & Utilization & Energy & & \\
\hline Estonia & 15 & & 15 & & 100.00 & 1 \\
\hline Hungary & 36 & & 27 & 9 & 100.00 & 1 \\
\hline Latvian & 9 & & 4 & 5 & 100.00 & 1 \\
\hline Romania & 34 & & 3 & 31 & 100.00 & 1 \\
\hline Slovenia & 15 & & 8 & 7 & 100.00 & 1 \\
\hline
\end{tabular}


ISSN 2345-0282 (online) http://jssidoi.org/jesi/ 2020 Volume 8 Number 2 (December)

http://doi.org/10.9770/jesi.2020.8.2(42)

Make your research more visible, join the Twitter account of ENTREPRENEURSHIP AND SUSTAINABILITY ISSUES: @Entrepr69728810

\begin{tabular}{|c|c|c|c|c|c|c|}
\hline Sweden & 80 & 20 & 19 & 40 & 98.75 & 2 \\
\hline Finland & 51 & 34 & 8 & 8 & 98.04 & 3 \\
\hline Denmark & 39 & & 38 & & 97.44 & 4 \\
\hline Austria & 63 & & 24 & 36 & 95.24 & 5 \\
\hline Poland & 169 & & 35 & 123 & 93.49 & 6 \\
\hline Greece & 34 & 1 & 15 & 14 & 88.24 & 7 \\
\hline Slovakia & 27 & & 17 & 6 & 85.19 & 8 \\
\hline Italy & 421 & 2 & 118 & 234 & 84.09 & 9 \\
\hline Norway & 39 & 2 & 11 & 18 & 79.49 & 10 \\
\hline Czech & 57 & & 17 & 28 & 78.95 & 11 \\
\hline Portugal & 84 & 1 & 38 & 27 & 78.57 & 12 \\
\hline Lithuania & 23 & & 9 & 9 & 78.26 & 13 \\
\hline Spain & 296 & 6 & 98 & 124 & 77.03 & 14 \\
\hline France & 457 & 33 & 92 & 227 & 77.02 & 15 \\
\hline Great Britain & 527 & 34 & 174 & 187 & 74.95 & 16 \\
\hline Belgium & 76 & & 45 & 10 & 72.37 & 17 \\
\hline Germany & 582 & & 201 & 212 & 70.96 & 18 \\
\hline Irish & 30 & & 12 & 9 & 70.00 & 19 \\
\hline Netherlands & 91 & 1 & 50 & 11 & 68.13 & 20 \\
\hline Bulgaria & 29 & & 15 & 4 & 65.52 & 21 \\
\hline Turkey & 260 & & 98 & 38 & 52.31 & 22 \\
\hline Cyprus & 5 & & & & 0 & 23 \\
\hline Malta & 1 & & & & 0 & 23 \\
\hline Switzerland & 40 & & & & 0 & 23 \\
\hline TOTAL & 3590 & 134 & 1191 & 1417 & 76.38 & \\
\hline
\end{tabular}

Source: compiled by the authors based on (Annual tire recycling report for Europe, 2017)

Analyzing the table data, it can be concluded that in countries such as Cyprus, Malta, and Switzerland there is no recycling production. First of all, this is due to the fact that these States are small and all tires that have failed are exported.

If we analyze the most popular tire recycling strategies used in Europe, we can note that only about $1 \%$ of the volume is disposed of (figure 2) (Kolganova, 2018). The most popular type of processing is the production of rubber crumb, which is later used for economic purposes, for example, for the manufacture of road surfaces. 
ENTREPRENEURSHIP AND SUSTAINABILITY ISSUES

ISSN 2345-0282 (online) http://jssidoi.org/jesi/

2020 Volume 8 Number 2 (December)

http://doi.org/10.9770/jesi.2020.8.2(42)

Make your research more visible, join the Twitter account of ENTREPRENEURSHIP AND SUSTAINABILITY ISSUES: @Entrepr69728810

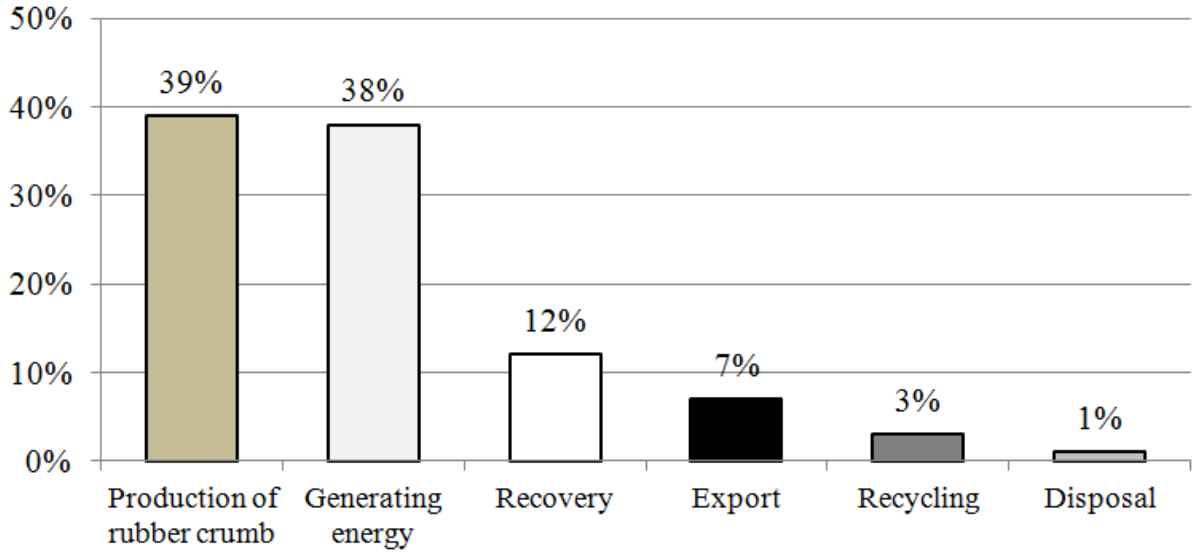

Fig. 2. Strategies for managing worn tires in Europe Source: compiled by the authors based on (Kolganova, 2018)

To sum up, it should be noted that thermal and mechanical processing are the most popular in Europe (figure 2). In addition, for most developed foreign countries, old tires are a source of valuable raw materials that are usually processed. This is fixed not only in normative documents, but primarily in the minds of the population. If we talk about the legal regulation of the process of recycling tire waste, it should be noted that in Europe, the treatment of worn tires is regulated by three main regulatory documents. By analyzing the international experience of waste tires, it becomes clear that the creation of an effective system of collection and further processing components, the active position of the state in this matter: regulation of the issue at the legislative level, the provision of subsidies to organizations involved in recycling, creating conditions to increase the attractiveness of the sector for its participants (Zvonov et al., 2000). If we talk about the financial side of the issue of recycling of worn tires, there are currently three models for financing the disposal of worn tires in the European Union (table 4).

Table 4. Systems for financing the recycling of used tires in Europe

\begin{tabular}{|l|l|l|}
\hline \multicolumn{1}{|c|}{ System } & \multicolumn{1}{|c|}{ Principle of functioning } & \multicolumn{1}{|c|}{ Countries that use this system } \\
\hline Tax System & $\begin{array}{l}\text { As part of this system, the state introduces tax payments, which serve } \\
\text { as the main source of subsidies for processing industries. }\end{array}$ & Hungary, Denmark, \\
& $\begin{array}{l}\text { Slovakia, Latvia } \\
\text { Producer Responsibility } \\
\text { financing for recycling processes is a fund to which tire manufacturers } \\
\text { costs in the cost of new tires. }\end{array}$ & $\begin{array}{l}\text { Sweden, Norway, } \\
\text { Finland, Portugal, } \\
\text { Poland, France. } \\
\text { The transition to this model is } \\
\text { expected in Great Britain, Spain, } \\
\text { Hungarians. }\end{array}$ \\
\hline Free Market System & $\begin{array}{l}\text { Each tire owner independently selects counterparty for tire recycling. } \\
\text { This model works effectively only in countries with a high standard of } \\
\text { living and a level of civil responsibility of the population. }\end{array}$ & \begin{tabular}{l} 
Germany, Italy \\
\hline
\end{tabular}
\end{tabular}

Source: compiled by the authors based on (Zvonov et al., 2000) 
Make your research more visible, join the Twitter account of ENTREPRENEURSHIP AND SUSTAINABILITY ISSUES: @Entrepr69728810

Today in Europe there are about 40 different companies involved in the recycling of old tires. The main goal of these companies is to collect and process tires in a quantity that would be comparable to the production of new tires. The principle that applies in Europe is "one new tire is sold - one old tire is recycled".

Figure 3 shows the dynamics of tire recycling in European countries. The figure shows that the trend of tire recycling is linear and increasing.

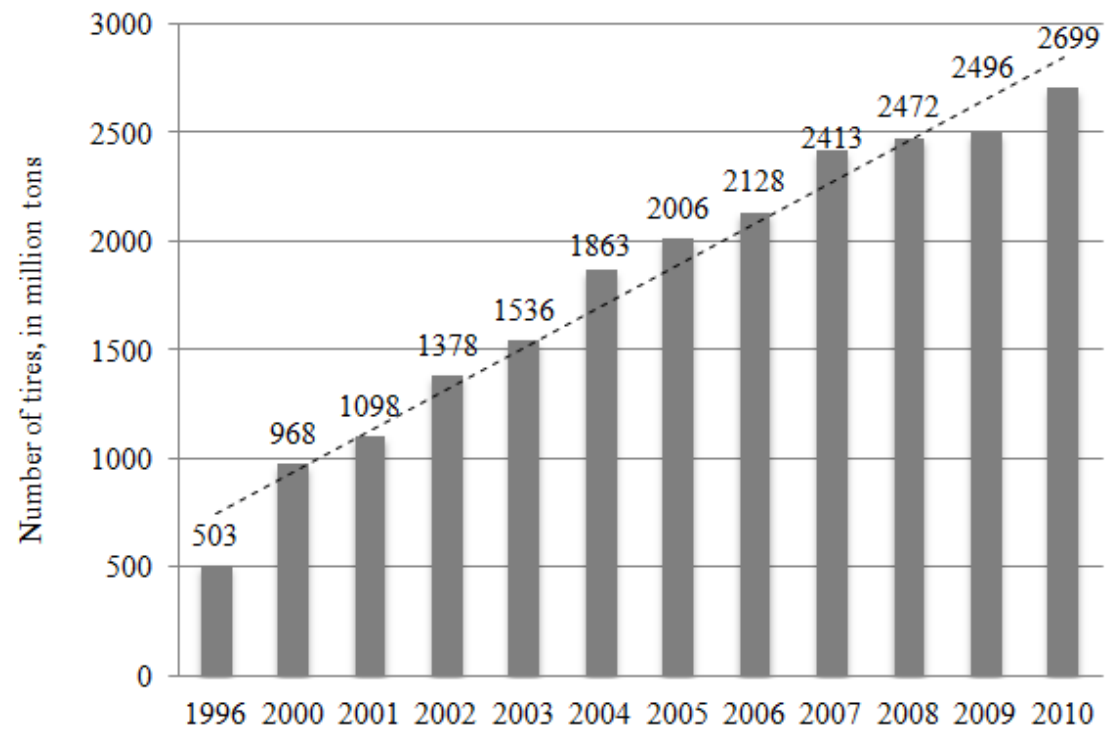

Fig. 3. Dynamics of car tire recycling in Europe

Source: compiled by the authors based on (Rostova et al., 2019)

Considering the issues of tire recycling in the United States, it should be noted that almost all States have adopted special laws and programs that regulate the management of tire waste. It is clear that each of the States has its own nuances regarding tire recycling. However, several similar principles can be identified in the analysis:

$\checkmark \quad$ financial support for tire recycling is provided by taxes and fees. For example, the amount of payment for the recycling of tires varies from 0.5 to $2 \$$ for passenger car tires, and from 3 to $5 \$$ for a truck; $\checkmark \quad$ tire recycling activities (assembly and processing plants) are subject to licensing; $\checkmark \quad$ participants in the recycling process: sorters and processors are provided with financial guarantees (Kolganova, Gubanova, 2018).

The Japanese tire recycling system is more than 18 years old. Currently, the country of the rising sun has a "law on waste recycling", according to which every citizen is obliged to personally deliver worn-out tires to the places where they are collected. At the same time, the recycling fee is 300 yen, which in terms of the Russian ruble is about 174 rubles. In parallel, in Japan, there is a law that imposes responsibility for the collection and disposal of tires on the manufacturers of new tires themselves. At the legislative level in Japan, it is stipulated that the reuse of resources obtained during recycling should be at least $70 \%$. 
ENTREPRENEURSHIP AND SUSTAINABILITY ISSUES

ISSN 2345-0282 (online) http://jssidoi.org/jesi/

2020 Volume 8 Number 2 (December)

http://doi.org/10.9770/jesi.2020.8.2(42)

Make your research more visible, join the Twitter account of ENTREPRENEURSHIP AND SUSTAINABILITY ISSUES: @Entrepr69728810

Analyzing the experience of tire recycling in Europe, Japan and the United States, we can draw the following conclusion: regulation of this issue by the state and responsibility, as well as the proactive position of citizens in relation to waste disposal, contribute to the development and effective operation of the industry of recycling old tires. Adopting the experience of the above-mentioned countries, you can achieve both economic benefits from organizing and conducting business activities in the field of recycling broken tires, and improve the environmental situation by recycling unnecessary waste.

\subsection{Analysis of Russian experience in tire recycling}

Currently, two concepts of urban development are applied in the Russian Federation: the concept of sustainable development, and the concept of smart city. One of the key aspects of these concepts is to improve the environmental situation in the country. Particularly, one of the most important environmental problems is environmental pollution due to the constant increase in tire waste. Therefore, recycling tires is a priority task in the sustainble development of the concept of smart cities in the Russian Federation. It not only reduces the consumption of material resources, but also is a priority in the development of environmental protection and environmental measures. Worn-out tires are subject to the Federal law of the Russian Federation of 1998 No. 89 FZ "on production and consumption waste". It is a waste of the fourth class of danger.

At the same time, the percentage of tire recycling in Russia is much lower than in European countries (Chistov, Pavlov, 2014). It is currently around 5\% to $20 \%$ according to various estimates (Stets, Chaykun, 2013), while in Europe this figure is approaching 80\%. According to "Shinoecology" data (Kolganova, 2018), about 1 million tons of worn-out tires are produced annually in Russia, the change in the dynamics of this indicator is shown in table 5 .

Table 5. Estimation of the total number of tires for recycling in the Russian Federation

\begin{tabular}{|c|c|c|c|}
\hline \multirow{2}{*}{} & The volume of waste tires in Russia, thousand tons & \multicolumn{2}{|c|}{ Utilization } \\
\cline { 3 - 4 } & & thousand tons & \\
\hline 2016 & 800.0 & - & 3.75 \\
\hline 2017 & 729.0 & 30 & 4.50 \\
\hline 2018 & 800.0 & 36 & 8.75 \\
\hline 2019 & 800.0 & 70 & - \\
\hline
\end{tabular}

Source: compiled by the authors based on (Kolganova, 2018)

The dynamics of growth in the number of tires is still maintained at the present time, as can be seen from figure 4. Moreover, both tires produced in the country and imported tires are subject to recycling on the territory of the Russian Federation. At the same time, as can be seen from figure 5, the share of both tires is growing every year. Moreover, if the trends continue, by 2021 the number of tires imported and produced annually in the Russian Federation will increase by almost 2 times. This makes recycling even more necessary (Shmelev et al., 2018). 
Make your research more visible, join the Twitter account of ENTREPRENEURSHIP AND SUSTAINABILITY ISSUES: @Entrepr69728810

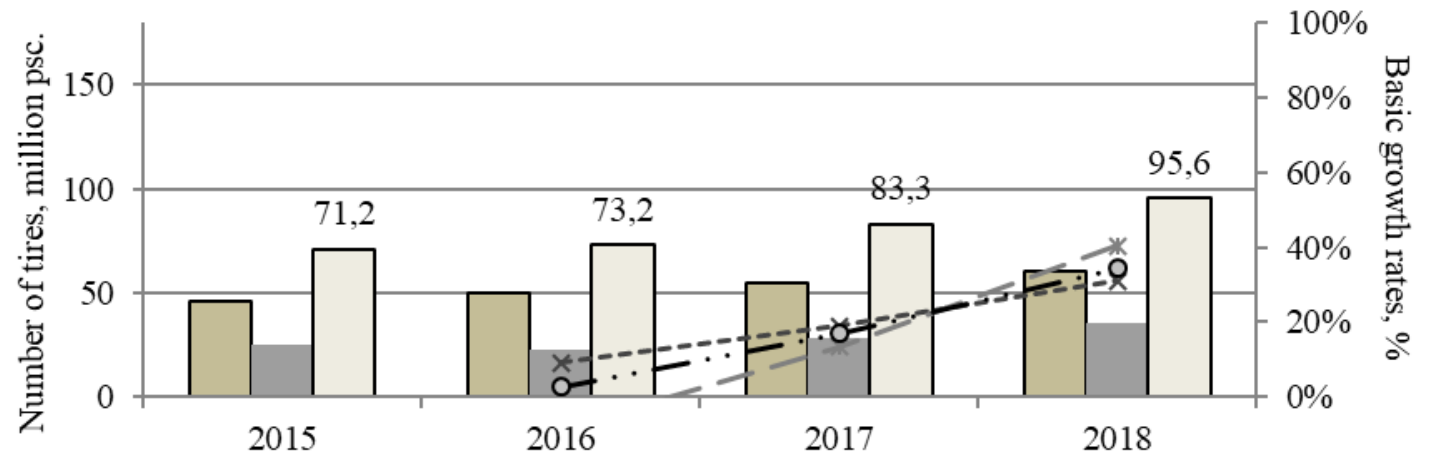

The volume of production in the country, million units

Tire imports, million pcs.

Annual increase in the number of tires, million pcs

--x--Basic growth rates of domestic tire production, $\%$

- - Basic growth rates of tire imports in Russia, \%

$\longrightarrow$. The basic rates of a total increase of tire, \%

Fig. 4. Analysis of the dynamics of the increase in the number of tires on the territory of the Russian Federation Source: compiled by the authors based on (Shmelev et al., 2018)

One of the main reasons for the growth of tire production is the increase in the provision of individuals and legal entities with vehicles. Thus, according to the analytical Agency "AUTOSTAT" at the beginning of 2018, the provision of passenger cars in the Russian Federation on average amounted to 290 units per 1000 residents (Rostova et al., 2019). This figure is twice the global average. However, it is significantly lower than the indicators of developed European countries. Almost every second Russian family has a private car, and every sixth has two or more of them.

Clearly, with an increase in the number of cars purchased, the number of tires purchased increases in direct proportion. At the same time, the climatic features of our country force us to purchase 2 types of rubber: for summer and winter time.

At the same time, in Russia, despite the state's policy to improve the environmental situation, citizens have formed an uncompromising attitude to secondary raw materials: for most Russians, this is just garbage, the recycling of which seems useless. In Russia, millions of old tires have accumulated, both in legal and illegal dumps. They are thrown along roadsides, on vacant lots, in courtyards, in forests, even used as fencing for flower beds (Grafkina, Mikhailov, Ivanov, 2009).

However, the transition to the concept of smart cities and the resulting increased attention to environmental issues have given rise to a number of legislative documents, including the decree of the Government of the Russian Federation dated December 28, 2017 No. 2971-R "on approval of standards for waste disposal from the use of goods for 2018-2020". In this document, the following standards for tire recycling were set for the group "Tires, tires and rubber chambers": $2018-20 \%, 2019-25 \%, 2020-30 \%$. 
Make your research more visible, join the Twitter account of ENTREPRENEURSHIP AND SUSTAINABILITY ISSUES: @Entrepr69728810

However, based on the analysis, it was revealed (table 6) that the plan approved in the decree about tire recycling was not fulfilled.

Table 6. Analysis of the implementation of the tire recycling plan

\begin{tabular}{|l|c|c|c|c|}
\hline \multirow{2}{*}{} & \multicolumn{2}{|c|}{ Utilization } & $\begin{array}{c}\text { Planned percentage of utilization } \\
\text { according to Decree, } \%\end{array}$ & $\begin{array}{c}\text { The percentage of the plan for } \\
\text { recycling tires, } \%\end{array}$ \\
\cline { 2 - 5 } & thousand tons & $\%$ & - & - \\
\hline 2017 & 30 & 3.75 & 20.0 & 22.5 \\
\hline 2019 & 36 & 4.50 & 25.0 & 35.0 \\
\hline
\end{tabular}

However, despite the fact that the standard for recycling tires in the Russian Federation has been increased by law, the situation still continues to be quite tense. Because the gap between standards and Western countries is significant - in Europe, this figure is approaching $80 \%$ (table 3 ).

Based on the analysis of the trend in the standard of tire recycling in Russia, if the rates set by the Government order are maintained, the Russian economy will be able to reach the average indicators of developed Western countries in 13 years, that is, by 2030 .

\subsection{Economic aspects of tire recycling in the Russian Federation}

It is clear that the adoption of the law on mandatory tire recycling raises a number of issues related to the financing of this event.

To solve this issue, Russia, by analogy with the leading Western countries, has introduced a recycling fee. Moreover, this fee is imposed in general on the purchase of a car, as well as on tires.

At the same time, the recycling fee is understood as a one-time payment in favor of the state, which is used to take environmental safety measures and protect human life and health from harmful emissions during the operation of the vehicle.

Speaking about vehicle recycling in General, then the payment of the recycling fee is regulated by the Federal Law "About production and consumption waste". The law provides for mandatory payment of a recycling fee when purchasing a car.

The amount of the recycling fee required for payment when purchasing a vehicle is calculated by multiplying the base rate by the calculation factor.

Talking about the amount of the base rate present in the formula for calculating the recycling fee, it varies depending on the type of vehicle and is:

\footnotetext{
$\checkmark \quad$ for non-commercial passenger cars - 20,000 rubles;

for commercial passenger cars, as well as trucks and buses $-150,000$ rubles.
} 
ENTREPRENEURSHIP AND SUSTAINABILITY ISSUES

ISSN 2345-0282 (online) http://jssidoi.org/jesi/

2020 Volume 8 Number 2 (December)

http://doi.org/10.9770/jesi.2020.8.2(42)

Make your research more visible, join the Twitter account of ENTREPRENEURSHIP AND SUSTAINABILITY ISSUES: @Entrepr69728810

The coefficient for calculating the amount depends on the year of manufacture of the car (other vehicle) and its parameters: size, weight, engine volume, and is regulated by the Decree of the Government of the Russian Federation No. 1291 of 26.12.2013.

The second direction is to receive a recycling fee from tire manufacturers. These companies are currently required to pay for recycling, as used car tires and cameras were included in the "list of types of production and consumption waste, which includes useful components, the disposal of which is prohibited" from January 1, 2019. The payment is different for the regions of the Russian Federation, so in Chelyabinsk they pay for the disposal of 1 ton of tires - 2000 rubles, in Krasnodar - 3500 rubles.

Recycling tires can be an important source of resource savings. So, if the weight of rubber is $70 \%$ of the weight of a worn tire (Afinogenov and et. al, 2016), then if the total volume of tires is processed, which in Russia is about 1 million tons per year (figure 4), you will get about 700,000 tons of rubber.

The saved raw materials can be used as raw materials for rubber products, construction materials, for example, can be used as road pavement.

At the same time, if you continue to burn worn tires, it is necessary to understand that 270 kilograms of soot and 450 kilograms of toxic waste will be released into the atmosphere (Afinogenov and et. al, 2016) per 1 ton of raw materials burned. If we assume that the entire volume of tires in Russia will be disposed of by incineration, then 270 million tons of soot and 450 million tons of gases will be released into the air.

These figures do not fit into the concept of smart cities. In this regard, the first place goes not only to the disposal of tire waste, but also to the use of environmentally friendly methods of their disposal.

\section{Conclusions}

According to the analysis of the international experience of urban development in accordance with the above concepts, one of the key areas of implementation of the concepts is the environmental aspect.

Almost all researchers agree on the need to resolve the issues related to waste disposal, which increases with the quality of life. Along with this, everyone notes the need to resolve issues with the growth of tire waste.

Despite the beginning of the implementation of sustainable development and smart city concepts, today Russian cities have much more significant issues than European ones. Based on the analysis, only about $20 \%$ of these wastes are currently disposed of, while in European countries this value is more than $80 \%$. This discrepancy leads to the need to apply international experience in solving the problem of tire waste disposal in Russian cities.

For example, analyzing the European experience, experts say that the model of "manufacturer and importer Responsibility" for tire recycling, which is used in most European countries that were able to completely free their territories from the rubble of worn tires in 10-15 years, should be applied in our country.

There are several main reasons for the existing of problems with utilization of automobile tires in Russia, among them: the lack of a developed market for collecting tires, and the lack of a market for the sale of products for processing worn tires. 


\section{ENTREPRENEURSHIP AND SUSTAINABILITY ISSUES}

ISSN 2345-0282 (online) http://jssidoi.org/jesi/

2020 Volume 8 Number 2 (December)

http://doi.org/10.9770/jesi.2020.8.2(42)

Make your research more visible, join the Twitter account of ENTREPRENEURSHIP AND SUSTAINABILITY ISSUES: @Entrepr69728810

At the same time, modern Russia is only developing in this area. Until recently, the state did not encourage the work of enterprises related to the handling of tires (collection, transportation, storage and processing). Car rubber processors were left to their own devices, as their activities were not regulated, and this type of activity is quite risky. But recently, a number of bills have been passed that have greatly improved the situation in this type of business. In addition, leasing companies are willing to work with equipment for recycling tires, which also has a positive effect on the activities of organizations.

Taking into account eco-friendly ways of recycling tire waste is becoming one of the important directions in the transition of Russian cities to the concept of Smart City".

\section{References}

Ahvenniemi, H., Huovila, A., Pinto-Seppä, I., Airaksinen, M. 2017. What are the differences between sustainable and smart cities?. Cities 60: 234-245. https://doi.org/10.1016/j.cities.2016.09.009

Annual tire recycling report for Europe 2017. - available at: https://www.etra-eu.org/

Arulrajaha, A., Mohammadinia, A., Maghoola, F., Horpibulsuk, S. 2019. Tire derived aggregates as a supplementary material with recycleddemolition concrete for pavement applications. Journal of Cleaner Production, 230: 129-136. https://doi.org/10.1016/j.jclepro.2019.05.084

Chistov, D.V., Pavlov I.M., 2014. Analysis of business processes in the development of investment projects. Moscow: Synergy, 421. Costi, P., Minciardi, R., Robba, M., Rovatti, M., Sacile, R., 2004. An environmentally sustainable decision model for urban solid waste management. Waste Management, 24(3): 277-295. https://doi.org/10.1016/S0956-053X(03)00126-0

Decree of the Government of the Russian Federation of December 28, 2017 No. 2971-r "On the standards for the disposal of waste from the use of goods for 2018-2020."

Dong, L., Fujita, T. 2015. Promotion of low-carbon city through industrial and urban system innovation: Japanese experience and China's practice. World Scientific Reference on Asia and the World Economy, 257-279. https://doi.org/10.1142/9789814578622_0033

Dong, L., Liang, H., Zhang, L., Gao, Z., Hu, M. 2017. Highlighting regional eco-industrial development: Life cycle benefits of an urban industrial symbiosis and implications in China. Ecological Modelling, 361: 164-176. https://doi.org/10.1016/j.ecolmodel.2017.07.032

Fagundes, L.D., Amorim, E.S., da Silva Lima, R. 2017. Action Research in Reverse Logistics for End-Of-Life Tire Recycling. Systemic Practice and Action Research, 30: 553-568. https://doi.org/10.1007/s11213-016-9408-1

Federal Law of the Russian Federation of 1998 No. 89-FL “On Production and Consumption Wastes.

Ghosh, A., Sarkar, J.P., Das, B. 2019. Sustainable Energy Recovery from Municipal Solid Waste (MSW) using Bio-reactor Landfills for Smart City Development. 1st IEEE International Conference on Sustainable Energy Technologies and Systems, ICSETS, 242-246. https://doi.org/10.1109/ICSETS.2019.8745334

Grafkina, M.V., Mikhailov, V.A., Ivanov, K.S. 2009. Ecology and environmental safety of a car. Moscow, FORUM, 2009.

Gupta, P.K., Shree, V., Hiremath, L., Rajendran, S. 2019. The use of modern technology in smart waste management and recycling: Artificial intelligence and machine learning. Studies in Computational Intelligence, 823: 173-188. https://doi.org/10.1007/978-3-030$\underline{12500-4 \_11}$ 


\section{ENTREPRENEURSHIP AND SUSTAINABILITY ISSUES}

ISSN 2345-0282 (online) http://jssidoi.org/jesi/

2020 Volume 8 Number 2 (December)

http://doi.org/10.9770/jesi.2020.8.2(42)

Make your research more visible, join the Twitter account of ENTREPRENEURSHIP AND SUSTAINABILITY ISSUES: @Entrepr69728810

Kolganova, N.V., Gubanova, E.V. 2018. Actual directions of increasing financial activity and solvency of the group of waste recycling. Models, systems, network in economics, technology, nature and society, 3(27): 59-70.

Liang, S., Zhang, T. 2012. Comparing urban solid waste recycling from the viewpoint of urban metabolism based on physical input-output model: A case of Suzhou in China. Waste Management, 32(1): 220-225. https://doi.org/10.1016/j.wasman.2011.08.018

Long, J. 2018. Automobile Electronic Control Network Design Based on CAN Bus. Proceedings of 3rd International Conference on Intelligent Transportation, Big Data and Smart City, ICITBS 2018: 9-12. https://doi.org/10.1109/ICITBS.2018.00010

Machado Junior, C., Ribeiro, D., Pereira, R., Bazanini, R., 2018. Do Brazilian cities want to become smart or sustainable? Journal of Cleaner Production, 199: 214-221. https://doi.org/10.1016/j.jclepro.2018.07.072

Marina Meireles Pereira, Ricardo Luiz Machado, Silvio Roberto Ignacio Pires, Pereira Dantas, M.J., Patricia Regina Zaluski, Enzo Morosini Frazzon 2018. Forecasting scrap tires returns in closed-loop supply chains in Brazil. Journal of Cleaner Production, 188: 741750. https://doi.org/10.1016/j.jclepro.2018.04.026

Maryono, M., Hasmantika, I.H., 2019. Preliminary Study of Smart Urban Waste Recycling in Semarang, Central-Java, Indonesia. IOP Conference Series: Earth and Environmental Science, 248 (1), 012048. https://doi.org/10.1088/1755-1315/248/1/012048

Nižetić, S., Djilali, N., Papadopoulos, A., Rodrigues, J., 2019. Smart technologies for promotion of energy efficiency, utilization of sustainable resources and waste management. Journal of Cleaner Production, 231: 565-591. https://doi.org/10.1016/j.jclepro.2019.04.397

Novikov, S., Amirova, E., Kosykh, E., Chudinovskikh, M., Nikolaevskaya, O., 2019. Strategic planning and management of high-tech developments and innovative technical solution. Research in World Economy, 10(3): 309-314. https://doi.org/10.5430/rwe.v10n3p309

Rostova, O., Shirokova, S., Sokolitsyna, N. 2019. Management of project for automation of investment control at industrial enterprise. IOP Conference Series: Materials Science and Engineering, 497(1): 012017. https://doi.org/10.1088/1757-899X/497/1/012017

Rostova, O., Shirokova, S., Sokolitsyna, N., Shmeleva, A. 2019. Management of investment process in alternative energy projects. E3S Web of Conferences, 110: 02032. https://doi.org/10.1051/e3sconf/201911002032

Sagar, M., Nibedita, K., Manohar, N., Lachit, P., Jayaramudu, J. 2018. A potential utilization of end-of-life tyres as recycled carbon black in EPDM rubber. Waste Management, 74: 110-122. https://doi.org/10.1016/j.wasman.2018.01.003

Saptadi, N.T.S., Chyan, P., Pratama, A.C., 2019. Geographic Information System for Waste Management for the Development of Smart City Governance. IOP Conference Series: Materials Science and Engineering, 854, 1: 012040. https://doi.org/10.1088/1757$\underline{899 X / 854 / 1 / 012040}$

Shmelev, S.E., Shmeleva, I.A., 2018. Global urban sustainability assessment: A multidimensional approach. Sustainable Development, 26(6): 904-920. https://doi.org/10.1002/sd.1887

Sienkiewicz, M., Janik, H., Borzeowska-Labuda, K., Kucinska-Lipka, J. 2017. Environmentally friendly polymer-rubber composites obtained from waste tyres: A review. Journal of Cleaner Production, 147: 560-571. https://doi.org/10.1016/j.jclepro.2017.01.121

Stets, A.A., Chaykun, A.M., 2013. Environmental and economic aspects of the processing and use of used car tires News MGTU "MAMI", 1(15): 34-45.

Tsai, W.-T., 2015. The Utilization of Scrap Tires as an Energy Source and Its Environmental Benefit Analysis in Taiwan. Energy Sources, Part B: Economics, Planning and Policy, 10(4): 333-339.

Urban world: Mapping the economic power of cities, 2011. https://www.mckinsey.com/featured-insights/urbanization/urban-worldmapping-the-economic-power-of-cities

Wang, Q.-Z., 2020. Waste tire recycling assessment: Road application potential and carbon emissions reduction analysis of crumb rubber modified asphalt in China, Journal of Cleaner Production. https://doi.org/10.1016/j.jclepro.2019.119411 


\section{ENTREPRENEURSHIP AND SUSTAINABILITY ISSUES}

ISSN 2345-0282 (online) http://jssidoi.org/jesi/

2020 Volume 8 Number 2 (December)

http://doi.org/10.9770/jesi.2020.8.2(42)

Make your research more visible, join the Twitter account of ENTREPRENEURSHIP AND SUSTAINABILITY ISSUES: @Entrepr69728810

Zhang, A., Venkatesh, V.G., Liu, Y., Wan, M., Qu, T., Huisingh, D., 2019. Barriers to smart waste management for a circular economy in China. Journal of Cleaner Production, 240: 118198. https://doi.org/10.1016/j.jclepro.2019.118198

Zhang, X., Bayulken, B., Skitmore, M., Lu, W., Huisingh, D., 2018. Sustainable urban transformations towards smarter, healthier cities: Theories, agendas and pathways. Journal of Cleaner Production, 173: 1-10. https://doi.org/10.1016/i.jclepro.2017.10.345

Zhao, Y., Gao, Y., Shi, Y., Dong, F., Wang, Y., 2018. New method for making and selecting the compaction plan of asphalt pavement based on compaction quality and carbon emissions. Journal of Cleaner Production, 181: 385-398. https://doi.org/10.1016/j.jclepro.2018.01.257

Zvonov, V.A., Kozlov, A.V., Kutenev, F.V. 2000. Ecological safety of the car in a full life cycle. Automotive industry, 11.

Tatyana KHUDYAKOVA is Doctor of Science (Economics) and the Head of the Department "Applied Economics" South Ural State University (National Research University), Russia. Research interests: entrepreneurship and regional development; innovation and small firms; small firm internationalization; sustainability. Scopus ID 57190005672.

ORCID ID: https://orcid.org/0000-0001-5397-0498

Andrey SHMIDT is Doctor of Science (Economics) and the Professor of the Department "Applied Economics" South Ural State University (National Research University) and prorector, Russia. Research interests: entrepreneurship and regional development; innovation and small firms; small firm internationalization; sustainability. Scopus ID 56712529300.

ORCID ID: https://orcid.org/0000-0003-3575-6898

Svetlana SHMIDT is undergraduate student of the Department "Mathematics and Computer Science" Saint-Petersburg State University, Russia. Research interests: application of mathematical methods in applied research and computer science.

ORCID ID: $\underline{\text { https://orcid.org/0000-0002-8967-0611 }}$

Copyright (C) 2020 by author(s) and VsI Entrepreneurship and Sustainability Center

This work is licensed under the Creative Commons Attribution International License (CC BY). http://creativecommons.org/licenses/by/4.0/

cc) (†) Open Access

